\title{
PENGEMBANGAN KOMPETENSI PENGASUH DALAM MENINGKATKAN KUALITAS PEMBINAAN PRAJA SEBAGAI KADER APARATUR PEMERINTAHAN DI KAMPUS INSTITUT PEMERINTAHAN DALAM NEGERI JATINANGOR TAHUN 2019-2020
}

\author{
Oleh \\ Satria Wijaya ${ }^{1}$, \\ Hyronimus Rowa ${ }^{2}$, Muhadam Labolo ${ }^{3}$ \\ ${ }^{1)}$ Institut Pemerintahan Dalam Negeri \\ Program Magister Terapan Studi Pemerintahan Daerah Institut Pemerintahan Dalam Negeri \\ satriawijayabengkulu@gmail.com \\ 2,3) Institut Pemerintahan Dalam Negeri
}

\begin{abstract}
“CARIER COMPETENCY DEVELOPMENT IN IMPROVING THE QUALITY OF PROGRAM DEVELOPMENT AS A GOVERNMENT OF THE GOVERNMENT APPARATUS IN THE GOVERNMENT INSTITUTE OF HOME AFFAIRS JATINANGOR 2019-2020"

$T$ This research focuses on describing and analyzing the development of competencies in improving the quality of Praja development as a cadre of government apparatus at the Governance Institue of Home Affairs at Jatinangor campus. Analyzing the factors in the development of nurturer competencies, the quality of nurturing and the strategy of the nurturer's part in improving the quality of nurturing. Researchers used the theory of competency development by Wibowo and the theory of quality coaching by T.R. Mitchell also analyzed the Sondang P. Siagian SWOT strategy to determine the nurturing strategy.

Researchers use qualitative theory by using descriptive. In collecting data, researchers conducted observations and collected documents about developing competencies in improving the quality of praja development as a cadre of the government apparatus. The results showed that 1) the development of nurturer competencies is needed to improve the quality of nurturing, the development of nurturer competencies by conducting education and training to improve the nurturer's knowledge, skills and attitudes in fostering Praja; 2) the quality of Praja can be achieved maximally if competence can be developed to the maximum, this can be seen from the quality of character development and personality of Praja that can be achieved with the quality of nurturer work that is the quality of parenting and caring material, speed and accuracy of nurturers in anticipating and solving problems, nurturer initiative in carrying out coaching to cadets, and the ability of nurturers in carrying out good nurturer guidance and communication both with Praja and with colleagues and supervisors; 3 ) The nurturer strategy to improve the quality of care is to recruit nurturers, create a nurturer curriculum, develop and develop nurturing SOPs, develop a life cycle for Praja, divide the ideal number of nurturers, implement punishments and awards for nurturers, and develop nurturers career.
\end{abstract}

Keywords: competence, quality of guidance, cadre of apparatus 


\begin{abstract}
AbSTRAK
$\mathrm{P}$ enelitian ini memfokuskan untuk mendeskripsikan dan menganalisis pengembangan kompetensi pengasuh dalam meningkatkan kualitas pembinaan praja sebagai kader aparatur pemerintahan pada Institut Pemerintahan Dalam Negeri kampus Jatinangor. Menganalisis faktor-faktor dalam pengembangan kompetensi pengasuh, kualitas pembinaan dan strategi bagian pengasuh dalam meningkatkan kualitas pembinaan. Peneliti menggunakan teori pengembangan kompetensi oleh Wibowo dan teori kualitas pembinaan oleh T.R. Mitchell serta melakukan analisis strategi SWOT Sondang P. Siagian untuk menganalisis strategi pengasuhan.

Peneliti menggunakan teori Kualitatif dengan pendekatan deskriptif. Dalam mengumpulkan data, peneliti melakukan observasi wawancara dan mengumpulkan dokumen tentang pengembangan kompetensi pengasuh dalam meningkatkan kualitas pembinaan praja sebagai kader aparatur pemerintahan. Hasil penelitian menunjukkan bahwa 1) pengembangan kompetensi pengasuh sangatlah dibutuhkan dalam meningkatkan kualitas pembinaan, pengembangan kompetensi pengasuh, yaitu dengan melakukan pendidikan dan pelatihan untuk meningkatkan pengetahuan, keterampilan dan sikap pengasuh dalam membina praja; 2) kualitas pembinaan praja dapat tercapai maksimal apabila kompetensi dapat dikembangkan secara maksimal, hal ini dapat dilihat dari Kualitas pembinaan karakter dan kepribadian praja dapat tercapai dengan kualitas pekerjaan pengasuh, yaitu kualitas pola asuh dan materi asuh, kecepatan dan ketepatan pengasuh dalam mengantisipasi dan menyelesaikan permasalahan, inisiatif pengasuh dalam melaksanakan pembinaan kepada praja, dan kemampuan pengasuh dalam melaksanakan pembinaan serta komunikasi pengasuh yang baik baik dengan praja maupun dengan rekan kerja dan atasan; 3) Strategi bagian pengasuhan untuk meningkatkan kualitas pembinaan, yaitu Melakukan rekruitmen pengasuh, Pembuatan kurikulum pengasuh, Pembuatan dan pengembangan SOP pengasuhan, Pengembangan siklus kehidupan praja, Pembagian jumlah pengasuh yang ideal, Menerapkan punishment dan penghargaan kepada pengasuh, dan Pengembangan karier pengasuh.
\end{abstract}

Kata kunci: kompetensi, kualitas pembinaan, kader aparatur

\title{
PENDAHULUAN
}

$\mathrm{P}$ erkembangan aparatur pemerintah memperlihatkan berbagai permasalahan dan tantangan terutama pada aspek SDM aparatur pemerintah yang belum optimal. Profesional dan manajemen kepegawaian aparatur masih sangatlah kurang baik di pemerintah daerah maupun pemerintah pusat. Tidak profesionalnya aparatur pemerintah dapat dilihat dari berbagai aspek seperti pelayanan publik, disiplin, kemampuan kerja, budaya kerja, prilaku dan etika, moralitas dan semangat kerja yang tinggi serta aspek lainnya yang menunjang profesionalismenya sebagai pegawai pemerintah.

Dari segi pelayanan publik masih banyak ditemukannya pelayanan yang

berbelit-belit dan dipersulit bahkan adanya kepentingan pribadi di atas kepentingan dinas. Dari segi aspek disiplin masih banyak aparatur yang tidak masuk kerja ataupun datang hanya absen dan kemudian pulang dengan bermacam alasan yang mengabaikan tugas pokoknya sebagai seorang aparatur pemerintah. Pada aspek kemampuan kerja masih banyak ditemukannya aparatur pemerintah yang tidak mumpuni di bidang yang ditugaskanya bahkan tidak sesuai dengan latar belakang pendidikannya. Pada aspek moralitas, etika dan prilaku masih didapati aparatur yang korupsi, kolusi dan nepotisme yang mana sebagai aparatur pemerintah merupakan abdi negara yang mempunyai tugas pokok melayani masyarakat. 
Awalnya, perkembangan sekolah kepamongprajaan di Indonesia tidak terlepas dari apa dan bagaimana pembelajaran ilmu pemerintahan, ilmu negara, ilmu politik, dan administrasi negara di Indonesia. Pada masa penjajahan kolonial Belanda, pembelajaran ilmu-ilmu ini sangat dilarang. Namun, di Negeri Belanda, pengkajian ilmu pemerintahan masih tetap dilakukan, bahkan berada di bawah ilmu politik. Dalam sejarah pendidikan pamong praja, pendidikan pamong praja pada zaman Hindia Belanda dikenal nama sekolah dengan nama seperti OSVIA (Opleiding School Voor Inlandsche Ambtenaren), MOSVIA (Middelbaar Opleiden Schoolen voor Indische Ambtenaren), dan MBS. Berdirinya sekolah pamong di Indonesia tak lepas dari kepentingan penjajah Belanda untuk memenuhi kebutuhan kader-kader pemerintahan saat itu.

Setelah Indonesia merdeka, pada 17 Maret 1956 berdirilah untuk pertama kali sekolah kepamongprajaan pribumi yang didirikan sebagai kelanjutan KDC (Sekolah Dinas C). Saat itu, Presiden RI pertama, Soekarno hadir dan menyampaikan pidato tentang pembentukan sumber daya manusia (human investment). Awalnya, sekolah ini diberi nama Akademi Pemerintahan Dalam Negeri(APDN) yang didirikan di dua puluh daerah.

Akademi Pemerintahan Dalam Negeri (APDN) pada 17 Maret 1956 di Malang, Jawa Timur berdasarkan SK Mendagri No. Pend. 1/20/565 tanggal 24 September 1956 dan diresmikan oleh Presiden Soekarno. Lulusan APDN akan mendapat gelar sarjana muda (BA) dan dirasa masih perlu dikembangkan lagi. Oleh karena itu, Pemerintah membentuk Institut Ilmu Pemerintahan (IIP) yang berkedudukan di Kota Malang Jawa Timur berdasarkan Keputusan Bersama Menteri Dalam Negeri dan Menteri Pendidikan dan Kebudayaan No. 8 Tahun 1967, selanjutnya dikukuhkan dengan Keputusan Presiden No. 119 Tahun 1967. Peresmian berdirinya IIP di Malang ditandai dengan peresmian oleh
Presiden Soekarno pada 25 Mei 1967. Pada 1972 IIP pindah ke Jakarta dan diresmikan oleh Presiden Soeharto.

Tahun 1989, kedua puluh APDN ini diintegrasikan menjadi satu wilayah di Jatinangor, Jawa Barat. Pada 14 Agustus 1992 berdasarkan Kepres No. 42 Tahun 1992 sekolah ini berubah nama menjadi STPDN (Sekolah Tinggi Pemerintahan Dalam Negeri) dan diresmikan oleh Presiden Soeharto. Setiap kelulusannya dikukuhkan oleh Presiden RI sebagai calon Pamong Praja Muda.

Integrasi STPDN (Sekolah Tinggi Pemerintahan Dalam Negeri) dan IIP (Institut Pemerintahan Dalam Negeri), sehingga terbit Keputusan Presiden No. 87 Tahun 2004 tentang Penggabungan Sekolah Tinggi Pemerintahan Dalam Negeri ke dalam Institut Ilmu Pemerintahan, dan kemudian namanya diubah menjadi Institut Pemerintahan Dalam Negeri (IPDN), menjadi landasan pertama penyebutan (atau lebih tepat lagi: pemaknaan) IPDN sebagai perguruan tinggi kepamongprajaan. Pemaknaan tersebut kemudian ditegaskan lagi dalam Peraturan Presiden No. 1 Tahun 2009 tentang Perubahan Atas Keputusan Presiden No. 87 Tahun 2004.

Visi IPDN, yaitu menjadi Pendidikan Tinggi Kepamongprajaan terpercaya dalam menghasilkan kader pemerintahan yang berkompetensi, berkarakter dan berkepribadian. IPDN bertujuan untuk:

a. menghasilkan kader aparatur pemerintah pusat dan daerah yang profesional, berkepribadian dan berkarakter;

b. memberikan kontribusi pemikiran kepada penyelenggaraan pemerintahan pusat dan daerah dalam hal perumusan kebijakan pemerintah; dan

c. memberikan kontribusi bagi pengembangan ilmu pemerintahan.

Adapun tujuan penulis melakukan penelitian adalah sebagai berikut. 
1. Untuk mengetahui pengembangan kompetensi pengasuh dalam meningkatkan kualitas pembinaan praja sebagai kader aparatur pemerintahan.

2. Untuk mengetahui strategi pengasuh dalam meningkatkan kualitas pembinaan praja sebagai kader aparatur pemerintahan.

\section{KAJIAN PUSTAKA}

Berdasarkan Pasal 52 Permendagri No. 42 Tahun 2018 disebutkan bahwa tenaga pendidik terdiri dari dosen, pelatih, dan pengasuh. Pengajaran mendidik peserta didik untuk memiliki pengetahuan yang luas yang tidak terpaku pada satu aspek pemerintahan saja namun segala aspek pemerintahan yang kemudian akan menjurus ke program studi masing-masing peserta didik. Dengan dibekali ilmu pengetahuan yang luas lulusan IPDN dapat menghadapi dunia kerja nantinya. Kemudian pelatihan, yang mana mengajarkan peserta didik keahliankeahlian yang akan digunakan dalam dunia kerja. Keahlian juga tidak terpaku pada satu aspek saja, peserta didik mendapatkan pelatihan-pelatihan pada setiap semester yang kemudian setiap 2 semester sekali akan melaksanakan praktik lapangan langsung pada dunia kerja nyata di berbagai pemerintahan daerah sesuai dengan prodi masing-masing peserta didik. Yang terakhir pengasuhan, yang mana pengasuhan membentuk karakter dan kepribadian peserta didik. Dalam siklus kehidupan peserta didik diatur untuk menjadi lebih disiplin, integritas, beretika, moralitas yang tinggi, kekompakan, gotong-royong, semngat kerja dan semangat juang yang tinggi serta fisik yang sehat dan kemudian menunjang pelaksanaan tugas baik selama proses pendidikan maupun dunia kerja nantinya.

Menurut Muhadam Labolo (2017: 289) IPDN semakin membenahi diri untuk meningkatkan kualitas lulusannya. Pada saat ini pengembangan sistem pengasuhan terus mengalami peningkatan menyesuaikan dengantuntutandankebutuhanzaman. Lewat aspek pengasuhan kita berharap terbentuk kesadaran individu sekaligus kesadaran kolektif yang bertumpu pada moralitas dan etika, apakah etika pendidikan yang kita sepakati sebagai modal bermasyarakat dan berpemerintahan, maupun moralitas agama yang menjadi fondasi paling kuno di muka bumi. Lewat kesadaran semacam itulah maka pengasuhan IPDN diharapkan mampu memberikan kontribusi signifikan bagi terbangunnya kesadaran seorang praja untuk mengubah dirinya, sekaligus secara kolektif mendorong dinamika masyarakat lewat prinsip good governance.

Peran pengasuh dalam pembentukan karakter di lingkungan wisma dan kehidupan sehari-hari pada peserta didik Institu Pemerintahan Dalam Negeri sangat penting sebagai pendidikan non formal. Satu wisma terdapat 2 lantai, satu lantai terdapat 2 orang pengasuh dan diisi 50-60 praja dengan latar belakang yang berbeda baik berbeda asal pendaftaran, berbeda bahasa dan budaya. Peran pengasuh tidak hanya mengawasi dan mengatur peserta didik namun juga sebagai seorang kakak atau orang tua bagi peserta didik yang memberikan motivasi, pembelajaran etika, dan teladan bagi peserta didik. Dengan rasio jumlah peserta didik dan pengasuh tersebut masih sangat kurang untuk memaksimalkan pendampingan, pengarahan dan pembentukan karakter peserta didik. Dalam hal ini, para pengasuh banyak mendampingi praja, peran dari pengasuh tidak hanya sebagai pentransfer ilmu akan tetapi lebih tanggung jawab dalam pembentukan karakter praja.

Untuk memaksimalkan peran pengasuh tersebut sehingga perlu adanya suatu materi asuh ataupun jam-jam pemberian materi asuh dari pengasuh kepada peserta didik pada siklus kehidupan praja. Materi asuh ini berisikan mengenai integritas, disiplin, wawasan kebangsaan dan daya juang, serta kebugaran bagi peserta didik. Sebagai 
pendidik non formal dengan adanya jamjam pemberian materi asuh tersebut maka dituntut pengasuh mempunyai kualifikasi dan keahlian-keahlian melalui pelatihanpelatihan secara terus menerus yang kemudian akan meningkatkan kualitas pengasuh dalam mencetak kader ASN dan lulusan IPDN.

Menurut Sondang P. Siagian (2000: 173) ada pembagian faktor-faktor strategis dalam analisis SWOT yaitu sebagai berikut.

1. Faktor berupa kekuatan

Yang dimaksud dengan faktor-faktor kekuatan yang dimiliki oleh suatu perusahaan termasuk satuan-satuan bisnis di dalamnya adalah antara lain kompetisi khusus yang terdapat dalam organisasi yang berakibat pada pemilikan keunggulan komparatif oleh unit usaha di pasaran. Dikatakan demikian karena satuan bisnis memiliki sumber keterampilan, produk andalan dan sebagainya yang membuatnya lebih kuat dari pada pesaing dalam memuaskan kebutuhan pasar yang sudah dan direncanakan akan dilayani oleh satuan usaha yang bersangkutan.

2. Faktor kelemahan

Yang dimaksud dengan kelemahan ialah keterbatasan atau kekurangan dalam hal sumber, keterampilan, dan kemampuan yang menjadi penghalang serius bagi penampilan kinerja organisasi yang memuaskan

3. Faktor peluang

Definisi peluang secara sederhana peluang ialah berbagai situasi lingkungan yang menguntungkan bagi suatu satuan bisnis.

4. Faktor ancaman

Pengertian ancaman merupakan kebalikan pengertian peluang, yaitu faktor-faktor lingkungan yang tidak menguntungkan suatu satuan bisnis jika jika tidak diatasi ancaman akan menjadi bahaya bagi satuan bisnis yang bersangkutan baik untuk masa sekarang maupun pada masa depan.

Menurut Wibowo (2007: 110) kompetensi adalah "suatu kemampuan untuk melaksanakan atau melakukan suatu pekerjaan atau tugas yang dilandasi atas keterampilan dan pengetahuan serta didukung oleh sikap kerja yang dituntut oleh pekerjaan tersebut". Dengan demikian, kompetensi menunjukkan keterampilan atau pengetahuan yang dicirikan oleh profesionalisme dalam suatu bidang tertentu sebagai sesuatu yang terpenting, sebagai unggulan bidang tertentu, dengan indikatornya adalah:

a. Pengetahuan (Knowledge)

Pengetahuan yang berkaitan dengan pekerjaan meliputi:

1. Mengetahui dan memahami pengetahuan di bidang masingmasing.

2. Mengetahui pengetahuan yang berhubungan dengan peraturan, prosedur, teknik yang baru dalam institusi pemerintahan.

b. Keterampilan (Skill)

Keterampilan individu meliputi:

1. Kemampuan dalam berkomunikasi dengan baik secara tulisan.

2. Kemampuan berkomunikasi dengan jelas secara lisan.

c. Sikap (Attitude)

Sikap individu meliputi:

1. Memiliki kemampuan dalam berkomunikasi dalam berkreativitas dalam bekerja.

2. Adanya semangat kerja yang tinggi.

Peningkatan kualitas suatu organisasi harus didukung dengan standar atau ukuran untuk menilai apakah suatu organisasi tersebut mempunyai kinerja baik atau tidak. 
Adapun beberapa faktor penentu kinerja menurut T.R. Mitchell dalam Sedarmayanti (2001: 51), menyatakan bahwa kinerja meliputi beberapa aspek berikut ini.

1. Quality of Work (kualitas pekerjaan), yaitu ukuran yang menyatakan seberapa jauh telah dipenuhi berbagai persyaratan, spesifikasi dan harapan yang dihasilkan dari suatu pekerjaan.

2. Promptness (kecepatan/ketepatan), menunjukkan waktu yang diperlakukan seseorang dalam menyelesaikan suatu pekerjaan.

3. Initiative (inisiatif), menunjukkan apresiasi seseorang terhadap pekerjaannya dengan berusaha mencari, menemukan dan mengembangkan metode-metode yang efektif untuk menyelesaikan pekerjaan tersebut dengan hasil yang gemilang.

4. Capability (kemampuan), potensi yang dimiliki seseorang dalam menyelesaikan pekerjaannya dengan efisien dan efektif.

5. Communication (komunikasi), ke mampuan seseorang dalam berinteraksi dengan sesama rekan sekerja maupun lingkungannya yang berguna untuk mendukung aktivitas pekerjaan.

Siklus kehidupan praja mengatur kehidupan sehari-hari praja dalam kehidupan berasrama dari bangun tidur sampai mereka tidur kembali dengan diawasi oleh pengasuh. Siklus ini diawali dengan bangun pagi melaksanakan ibadah dan aerobik pukul 04.30 diakhiri jam wajib belajar dan istirahat malam pukul 22.00. Siklus ini mengatur juga tahapann pelaksanaan pengajaran, pelatihan, ekstrakulikuler, dan jam wajib belajar pada malam hari.

Dalam melaksanakan siklus kehidupan praja pengasuh membimbing, mengarahkan dan mengawasi praja serta pengasuh memberikan reward dan punishment, apabila peserta didik mampu melaksanakan dengan baik maka diberikan reward, dan sebaliknya apabila peserta didik tidak melaksanakan siklus dengan baik akan diberi punishment sesuai dengan Peraturan Tata Kehidupan Praja.

Reward dan punishment merupakan hal yang sangat penting untuk memotivasi praja dalam melaksanakan kegiatan, karna dengan adanya reward dan punishment praja akan melaksanakan kegiatan dengan lebih berkualitas dan bertanggung jawab. Tujuan penerapan reward dan punishment juga mendorong praja untuk lebih aktif dan mendapatkan nilai positif sebanyakbanyaknya.

Berbagai tahapann perkembangan tumbuhan dapat dianalogikan sebagai penentu dalam membentuk karakter praja ataupun peserta didik melalui pola pengasuhan di lingkungan IPDN, hal ini menandakan bahwa seluruh tahapann yang harus dilalui oleh seorang praja dalam menjalani pendidikan selama empat tahun tercermin dalam fase-fase yang dialami tumbuhan saat menjalani siklus kehidupan menjadi dewasa. Adapun analogi fase perkembangan pertumbuhan tersebut dapat dikelompokkan sebagai berikut.

1. Praja Tingkat I (Muda Praja) dianalogikan dengan Masa Penanaman

2. Praja tingkat II (Madya Praja) dianalogikan dengan Masa Pertumbuhan

3. Praja tingkat III (Nindya Praja) dianalogikan dengan Masa Perkembangan

4. Praja tingkat IV (Praja Utama) dianalogikan dengan Masa Pendewasaan. (muhadamlabolo.blogspot.com, diakses tanggal 24 oktober 2019).

Dari pengelompokan di atas terlihat jelas bahwa setiap tingkatan kehidupan praja dianalogikan dengan tiap-tiap fase perkembangan tumbuhan, sehingga dapat dimaknai dengan pemberian perlakuan yang sama jika diterapkan dalam siklus kehidupan praja selama empat tahun menjalankan pendidikan. 
Bagi para peserta didikyangbaru masuk tentulah bukan hal mudah untuk dapat menyesuaikan dengan pola pengasuhan di IPDN ini, apalagi bagi mereka yang dulunya belum terbiasa hidup di asrama dan jauh dari orang tua, akan terasa sangat berat melakukan penyesuaian awal di kampus ini.

Pola pendekatan pengasuh sangatlah membutuhkan komitmen dan konsistensi dari seorang pengasuh dalam menerapkan kepada peserta didik. Dalam pelaksanaannya pengasuh bertanggung jawab terhadap peserta didik selama 24 jam dalam dan 7 hari dalam seminggu, mengarahkan dan mendampingi setiap kegiatan pengasuhan. Kegiatan pengasuhan juga merupakan proses yang berjalan secara simultan dan terintegrasi dengan upaya-upaya pendidikan lainnya. Kegiatan pengasuhan sebagai bagian dari upaya pendidikan kedinasan dilaksanakan dalam rangka menumbuhkan, mengembangkan dan memantapkan kepribadian peserta didik yang berkarakter agar memiliki nilai-nilai moral, etika dan sebagai kader pemerintahan yang mempunyai karakter kepamongprajaan, cerdas, dan terampil.

a. Karakter, pola pikir, dan moralitas pengasuh juga sangatlah penting dalam membina praja sehari-hari yang kemudian akan berpengaruh terhadap perkembangan peserta didik dalam mendampingi, mengarahkan, dan memberi keteladanan serta kepemimpinan yang menjadi contoh untuk membiasakan peserta didik dengan siklus kehidupan praja yang disiplin, sehat, tertib, rapi dan mempunyai moralitas yang tinggi.

b. Karakter, pola pikir, dan moralitas pengasuh juga sangat berpengaruh terhadap siklus kehidupan dan sistem pengasuhan. Hal ini dapat dinilai dari tiap-tiap pengasuh yang berbeda karakter dan cara dalam mengasuh praja sehingga tentu dapat memengaruhi siklus kehidupan yang berjalan. Sistem pengasuhan pun sangat tergantung pada tiap pengasuh dalam mengimplementasikan profesinalitasnya sebagai pengasuh. Saat ini siklus kehidupan praja dapat dikatakan berjalan dengan cukup baik namun perlu adanya suatu kurikulum mengenai jam ajar pengasuh sehingga dapat terukur dan terarah. Hal ini terlihat dari tingkat kedisiplinan praja yang meningkat dari tiap angkatan sebelumnya dalam setiap mengikuti kegiatan wajib praja. Hal tersebut menjadi cerminan dalam pola pembinaan yang dilakukan oleh pengasuh terhadap praja.

Pengembangan karier juga sangatlah dibutuhkan oleh pengasuh sebagai Aparatur Sipil Negara. Pada saat ini masih belum adanya suatu arah dan alur dari pengembangan karier pengasuh tersebut, pengembangan karier ini menjadi suatu motivasi bagi pengasuh dalam melaksanakan tugas mendidik peserta didik. Pengembangan karier bisa pada internal ataupun eksternal IPDN. Dengan bekal pelatihan-pelatihan, pengetahuan, dan jam asuh pengasuh bisa menjadi penunjang pengasuh dalam meningkatkan karier ke depannya.

Sistem pengasuhan IPDN sebagai ruh pembentukan karakter dan kepribadian praja yang selama ini dilaksanakan dalam operasionalisasinya banyak terdapat kondisi-kondisi yang diperlukan perubahanperubahan seiring kebutuhan pengguna baik daerah maupun pusat yang kemudian menimbulkan permasalahan dan menjadi pembiasan dari konsep dasarnya, sehingga diperlukan pengembangan pengasuhan yang lebih berkompeten dalam rangka meningkatkan kualitas pembinaan praja sebagai kader aparatur pemerintahan dalam negeri yang paripurna dalam melayani masyarakat. 


\section{METODE PENELITIAN}

Penelitian ini menggunakan model penelitian kualitatif. Penelitian kualitatif bertujuan memperoleh gambaran seutuhnya mengenai suatu hal menurut pandangan manusia yang diteliti.

Penulisan mendeskripsikan data-data yang diperoleh secara langsung dari pihak Bagian pengasuhan IPDN Kampus Jatinangor dan praja utama putra dan putri angkatan XXVII. Data tersebut dideskripsikan sesuai dengan keadaan nyata di lapangan dan dibandingkan dengan teori yang sudah ada dan menjadi dasar dari penelitian ini. Penelitian memaparkan dengan berhati-hati dan apa adanya tanpa merekayasa keadaan yang nyata terjadi di bagian pengasuhan IPDN Kampus Jatinangor.

Subjek penelitian ini adalah pengasuh dan seluruh praja utama (peserta didik tingkat Akhir) angkatan XXVII baik putra dan putri serta mewakili daerah asal pendaftaran selruh indonesia yang ada pada IPDN. Objek dari penelitian adalah strategi pengembangan kompetensi pengasuh dalam meningkatkan kualitas pembinaan kepada praja studi tahun 2018-2019 kampus ipdn jatinangor serta pada praja utama yang telah berproses selama 3 tahun terhadap pengasuh yang mereka rasakan.

Jenis sumber data adalah mengenai dari mana data diperoleh. Apakah data diperoleh dari sumber langsung (data primer) atau data diperoleh dari sumber tidak langsung (data sekunder). Prosedur pengumpulan data adalah cara-cara yang dapat digunakan oleh peneliti untuk mengumpulkan data. Peneliti menggunakan beberapa metode pengumpulan data, yaitu observasi, wawancara, dokumentasi, dan teknik angket.

\section{HASIL PENELITIAN DAN PEMBAHASAN}

Kompetensi Pengasuh Praja Institut Pemerintahan dalam Negeri masih perlu pengembangan dan pembaruan. Hal itu dibuktikandenganpengetahuan,keterampilan dan sikap yang dimiliki pengasuh sangat mendukung dalam pelaksanakan tugas melingkupi pengetahuan, keterampilan dan sikap seorang pengasuh. Akan tetapi kualitas pengasuh relatif masih kurang dan perlu pengembangan serta pembaruan sehingga kualitas pembinaan kepada praja semakin meningkat dan sesuai dengan kebutuhan zaman. Pengetahuan tentang cara mengasuh dan materi pengasuhan serta pengetahuan kepamongprajaan sangat dibutuhkan seorang pengasuh dalam melakukan pembinaan yang kemudian didukung dengan kemampuan seorang pengasuh dalam pemanfaatan teknologi, kepemimpinan Pamong Praja, public speaking dan komunikasi pengasuh serta sikap seorang pengasuh yang menjadi contoh dalam pembentukan karakter dan kepribadian praja.

Kualitas pembinaan praja yang baik akan menciptakan kader aparatur pemerintahan yang baik. Kualitas pembinaan praja dapat tercapai dengan mengacu kepada kualitas sumber daya pengasuh dalam melaksanakan tugasnya. Semakin bagus sumber daya pengasuh maka semakin tinggi kinerja pengasuh untuk meningkatkan kualitas pembinaan kepada praja. Dua hal yang dievaluasi dalam menilai kinerja pengasuh, yaitu perilaku dan kualitas kerja pengasuh. Penilaian perilaku pengasuh terdiri dari disiplin, moralitas, integritas, komitmen, konsisten, tanggung jawab dan komunikasi pengasuh.Sedangkan kualitas kerja pengasuh adalah memaksimalkan pola asuh dan kurikulum pengasuhan dalam membentuk karakter dan kepribadian praja. Kualitas pembinaan karakter dan kepribadian praja dapat tercapai dengan kualitas pekerjaan pengasuh, yaitu kualitas pola asuh dan materi asuh, kecepatan dan ketepatan pengasuh dalam mengantisipasi dan menyelesaikan permasalahan, inisiatif pengasuh dalam melaksanakan pembinaan kepada praja, dan kemampuan pengasuh dalam melaksanakan pembinaan serta komunikasi pengasuh yang 
baik dengan praja maupun dengan rekan kerja dan atasan.

Berdasarkan hasil penelitian dan wawancara serta observasi di bagian pengasuhan terdapat beberapa strategi dalam pengembangan kompetensi pengasuh dan peningkatan kualitas pembinaan, yaitu sebagai berikut.

1. Melakukan rekruitmen pengasuh dengan memperhatikan passion, jumlah pengasuh sesuai dengan kebutuhan dan penyaringan melalui beberapa kriteria lainnya sebagai seorang pengasuh. Kriteria tersebut harus sejalan dengan karakteristik pengasuh sendiri yang memiliki passion di bidangnya dalam mengemong praja sehingga kualitas pengasuhan bagian pengasuhan menjadi optimal.

2. Pembuatan kurikulum pengasuhan, yaitu dengan rencana pembelajaran semester yang berisikan Mental Ideologi, mental kepribadian, Kepemimpinan Kepamongprajaan, dan kebugaran jasmani yang berdasarkan tahapanntahapann setiap semester seperti anatomi tumbuhan di mana semester I dan II, yaitu penanaman, semester III dan IV, yaitu penumbuhan, semester $\mathrm{V}$ dan VI, yaitu pendewasaan dan semester VII serta VIII, yaitu pendewasaan.

3. Pembuatan dan pengembangan SOP sebagai dasar dalam melaksanakan operasional pengasuhan yang berisikan serangkaian instruksi tertulis yang dibakukan mengenai berbagai proses penyelenggaraan administrasi pengasuhan, bagaimana dan kapan harus dilakukan, di mana dan oleh siapa saja dilakukan.

4. Pengembangan siklus kehidupan praja sesuai dengan kebutuhan zaman. Pengembangan siklus kehidupan praja merupakan proses perbaikan atau pembenahan dalam siklus yang dijalankan oleh praja agar sistem pengasuhan tetap berjalan dengan baik.
5. Pembagian jumlah pengasuh yang ideal mengingat bagian pengasuhan masih kekurangan pengasuh terutama pada pengasuh putri. Dengan adanya pembagian pengasuh, idealnya setiap wisma terdapat keterwakilan pengasuh sehingga operaional pengasuhan dapat tetap berjalan dengan baik dalam membentuk karakter dan kepribadian praja.

6. Menerapkan reward dan punishment kepada pengasuh.

Penghargaan adalah sebuah bentuk apresiasi kepada suatu prestasi tertentu yang diberikan kepada pengasuh bila telah mendapatkan kegiatan positive maupun terdapat punishment, yakni hukuman yang didapatkan pengasuh dalam menjalankan tugasnya agar dapat mengarahkan tingkah laku yang berlaku secara umum.

Pada bagian pengasuhan terdapat penghargaan bagi pengasuh yang berprestasi seperti promosi pada jabatan yang ada di IPDN. Begitu juga apabila ada pengasuh yang tidak sesuai dengan tugas dan fungsinya maka mendapat teguran dari bagian pengasuhan. Hal ini menjadi motivasi bagi pengasuh untuk dapat menunjukkan kualitas diri dengan kualitas pembinaan terhadap praja yang menjadi tanggung jawabnya.

7. Melakukan survei tingkat kepuasan Praja terhadap sistem pembinaan Pengasuh dan fasilitas pengasuhan sebagi evaluasi dan pembaruan sistem pembinaan praja pada bagian pengasuhan.

8. Pengembangan karier pengasuh. Dalam pengembangan karier pengasuh merupakan sebagai kegiatan kepegawaian untuk membantu pengasuh dalam merencanakan karier pada masa depan baik pada lembaga IPDN maupun pada lembaga-lembaga lain di luar IPDN. Sehingga dengan adanya pengembangan karier ini pengasuh dan lembaga dapat mengembangkan diri secara optimal. 


\section{SIMPULAN}

Pengembangan kompetensi pengasuh sangatlah dibutuhkan dalam meningkatkan kualitas pembinaan kepada praja. Dengan kualitas pembinaan yang baik akan timbul kader aparatur pemerintahan yang baik.

Terdapat beberapa strategi dalam pengembangan kompetensi pengasuh dan peningkatan kualitas pembinaan, yaitu rekruitmen pengasuh dengan memperhatikan passion, Pembuatan kurikulum pengasuhan, Pembuatan dan pengembangan SOP, pengembangan siklus kehidupan praja, pembagian jumlah pengasuh yang ideal, menerapkan reward dan punishment kepada pengasuh, melakukan survei tingkat kepuasan praja, dan pengembangan karier pengasuh.

\section{SARAN}

Upaya untuk lebih meningkatkan kompetensi pengasuh praja Institut Pemerintahan Dalam Negeri Kampus Jatinangor terdapat beberapa hal yang harus mendapat perhatian khusus dari pihak lembaga IPDN dan pimpinan IPDN berikut ini.

1. Pengembangan kompetensi pengasuh dalam meningkatkan kualitas pembinaan kepada praja, yaitu dengan meningkatkan Sumber Daya Manusia pengasuh dengan pemberian pengetahuan khusus, kemampuan dalam mengasuh serta sikap yang baik dalam mengasuh praja. Kualitas pembinaan praja dalam membentuk karakter dan kepribadian akan tercipta dengan maksimal apabila kompetensi pengasuh telah meningkat dan berkembang. Dengan harapan lembaga dapat memprioritaskan pengasuh dalam pendidikan pelatihan terkait dengan cara mengasuh, kemampuan dalam mengasuh dan sikap sebagai pengasuh sehingga visi dan misi IPDN dapat tercapai dengan baik, yaitu menjadikan praja yang berkarakter dan berkepribadian.
2. Melaksanakan dan mengembangkan kembali strategi yang telah ada sehingga kualitas pembinaan kepada praja semakin meningkat. Rekruitmen pengasuh sangatlah penting, apabila pengasuh tidak sesuai dengan passion dan tidak memenuhi kriteria pengasuh maka pengasuh tersebut akan rendah sikapnya dalam mengasuh hal ini kemudian dapat merusak sistem pengasuhan yang sudah baik. Dengan Rencana Pembelajaran Semester (RPS) menjadi dasar bagi pengasuh dalam melakukan pola asuh dan pemberian materi asuh dalam kehidupan seharihari praja yang dibingkai dengan siklus kehidupan praja. SOP sangatlah penting bagi seorang pengasuh dalam melaksanakan tugas dalam membina praja sehingga menjadi pedoman bagi pengasuh dalam melaksanakan kegiatan dan mengambil tindakan dengan cepat dan tepat apabila ada permasalahan. Penghargaan dan pengembangan karier seorangpengasuh harus dapatterlaksana karena dapat menjadi motivasi bagi pengasuh dalam melaksanakan tugas dengan baik.

\section{DAFTAR PUSTAKA}

Almaroky, Wahyudi. 2015. Metamorfosis Sekolah Pamong: Dari OSVIA ke IPDN. Kompasiana beyond blogging,

Labolo, Muhadam dan Averus Toana, Ahmad. 2017. Kepamongprajaan di Indonesia. Bogor: Ghalia Indonesia.

Labolo, Muhadam dan Oktabri, Ahmad, Zulfikri. 2013. Filosofi pengasuhan, (Online), muhadamlabolo.blogspot.com, diakses tanggal 24 oktober 2019.

Sedarmayanti. 2001. Sumber Daya Manusia dan Produktivitas Kerja. Bandung: Mandar Maju.

Siagan, Sondang P. 2015. Manajemen Sumber Daya Manusia. Jakarta: PT Bumi Aksara.

Wibowo. 2007. Manajemen Kinerja. Jakarta: PT Raja Grafindo Persada. 